\title{
ADDING UNPAID WORK VALUE TO INCOME INEQUALITY MEASURES IN SLOVAKIA
}

\author{
ANNA VALLUŠOVÁa, ${ }^{*}$, ŽANETA LACOVÁa \\ anna.vallusova@umb.sk, zaneta.lacova@umb.sk \\ a Matej Bel University in Banská Bystrica, Faculty of Economics, Department of Economics, Tajovského 10, \\ Banská Bystrica, Slovakia
}

\begin{abstract}
Income inequality represents one of the central issues that are widely discussed by present-day economists. In Slovakia, significant income inequality linked to disparities between regions persists. The central aim of our paper is to offer an alternative insight into the issue of income inequality measurement by adjusting indicators of household income by the value of households' unpaid work. Our analysis combines data about Slovak households from the Luxembourg Income Study and from an original unpaid work study in Slovakia. Traditional inequality measures (Gini coefficient, Atkinson index and percentile ratios) are applied at the regional level. Our results show that income inequality and regional disparities measures become more favourable after incorporating the value of work done by households. Thus, a need to recognise the value of unpaid work in national accounting systems and in economic policy actions is underlined.
\end{abstract}

\section{Key words}

household income, income inequality measurement, unpaid work, regional disparities, Slovakia

\section{JEL classification}

D13, D31, J22

\section{Introduction}

Generally speaking, we can distinguish between macroeconomic and microeconomic approach to measuring the income. From the macroeconomic perspective, it is important to construct such an income aggregate that "fits the economy as the whole" and categorize it according to "type of transaction which gives rise to the flow without regard to the medium in which payment is made". Respecting this principle, disposable income methodology is usually applied at the macroeconomic level. From the microeconomic viewpoint, the conceptual definition is mainly driven by "what individual perceives to be an income receipt of direct benefit to himself" i. e. the means of payment is a major discriminatory factor. The major question which is addressed by micro analysts is: "Is the income receiving unit better off today as a result of this receipt (able to consume more goods and services)?" (United Nations Economic Commission for Europe, 2011, p. 12). More recently, microeconomic approach to income is more focusing on household income instead of individual income (Molina, 2011). Household income thus represents a measure of the combined incomes of all people sharing a particular household or place of residence. It is beyond the scope of the paper to describe the discussion on the pros and cons of various conceptual and practical approaches to measuring household income. However, it is necessary to stress, that the concept of welfare and financial well-being is essential concerning the microeconomic approach to measuring income. The idea is also expressed by Hicks who defines income as "maximum value which he can consume during a week, and still expect to be as well off at the end of period as he was at the beginning" (Procházka, 2009). 
In addition to disposable "money" income (Brouen et al., 2016), the level of household consumption is also influenced by non-cash and non-market receipts from which household production for own consumption is most evident. To take into account the contribution of the household production to wellbeing the household, Folbre et al. (2013) propose the measure of extended income. From the conceptual perspective, the authors define it as "the sum of aftertax earnings, other after-tax income (including government transfers) and the value of in-kind services provided by government, including health care, child care, and elder care, as well as the value of home production" (Folbre et al., 2013, p.237). From the practical point of view, possibilities of measuring extended income are limited by availability and quality of the data.

Concerning the issue of measuring the value of household production, from the practical point of view, it is impossible to express the output of unpaid work in monetary terms. It is firstly, because of the fact that the household production does not pass through the market and there is no market price, secondly, because the quality of the production varies notably among households. Therefore, the input approach is used to assess the value of unpaid work. The main input to home production is the time of its performer. There are two possibilities of evaluation of the time here. Firstly, the value of time is estimated by its alternative usage (i. e. opportunity costs), in this context using the forgone wage, or secondly, replacement costs are employed into the calculation. By replacement costs, we mean the wage of worker providing comparable services at market (Kaščáková, 2016). Usually, minimal wage in the economy is sufficient estimate as it is not necessary to have any special qualification to provide services similar to home production.

In order to analyse household welfare, it is necessary to discuss the issue of economies of scale and consequently necessity of employing equivalence scale to the analysis. Equivalence scales are "designed to adjust income to account for differences in need due to differences in household size and composition" (United Nations Economic Commision for Europe, 2011). The simplest adjustment is calculation of per-capita income. In context of household welfare, it is reasonable to assume that for achieving the same level of wellbeing of two-member household in comparison to single-member household it is not necessary to have double income. In other words, a couple, who shares dwelling and income, can afford higher level of total consumption than a person living alone assuming that their per-capita income is the same. It is predominantly effect of possibility to share certain consumption like accommodation or transportation. The economies of scale are even more obvious when the members of households are children, whose consumption tends to be cheaper in comparison to an adult member. To account for this, different versions of equivalence scales assign to each additional household member a weight lower than one to calculate weighted average of household income.

As to the household production, the economies of scale are even higher as the most important input is time of the household members. Costs of a dinner in the restaurant increase linearly with number of participants, while increasing number of servings requires little extra time when the dinner is prepared by household itself. Exception is the presence of very small child, who requires significant time investment in comparison to adults. However, another child brings economies of scale in "costs of rearing" as well.

To account for scale economies, variety of equivalence scales are used. Typically, we can distinguish between single-parameter, two-parameter or three parameter equivalence scale. An example of using single parameter scale is dividing household income by square root of household members. The parameter in question is the exponent 0.5 which lies in the middle of two extremes: simple per capita adjustment (exponent equal to 1) and no adjustment at all (exponent equal to 0). In addition to the exponent (which represents the economies of scale), two parameter equivalence scale introduce also additional parameter which captures needs of children relative to adults. Three parameter scales assign different weights to first adult than to additional adult (e. g. OECD scale). By using equivalence scale separately for market income 
and less rivalrous household production we can account for the different nature of their economies of scale (Folbre and Murray Close, 2014).

\section{Material and methods}

The main aim of our analysis tries is to offer an alternative perspective to the issue of income inequality measurement. To do so, we compare values of income inequality and regional disparities measures for disposable household income with those of extended income adding the value of unpaid work to "traditional" household income.

As being stressed by Monfort (2008), the most popular measures of income inequality are Gini coefficient and Atkinson index. The Gini coefficient is commonly used as a measure of inequality in the distribution of household income or wealth. A low value indicates more equal distribution ( 0 corresponding to perfect equality), while a high Gini coefficient indicates more unequal distribution (1 corresponding to perfect inequality where income is concentrated in the hands of one household). The Atkinson index is able to emphasise movements in particular segments of the distribution. Specifically, a parameter entering into the computation of the index allows for giving more or less weight to changes in a given portion of the income distribution. This parameter, known as the level of "inequality aversion", is generally denoted by $\varepsilon$. The Atkinson index becomes more sensitive to changes at the lower end of the distribution (low income or GDP per head levels) as $\varepsilon$ approaches $\infty$. Conversely, as the level of inequality aversion falls, that is as $\varepsilon$ approaches 0 , the index becomes more sensitive to changes in the upper end of the income distribution.

Our analysis is based on Luxemburg Income Study (LIS) data provided by LIS crossnational data centre. It is harmonized socio-economic micro datasets from upper- and middleincome countries. The main reason for using this dataset in our study is that it provides quality representative data on household income. The data on household production are imputed to the database from own survey conducted within the project VEGA 1/0621/17 "Decision-making of Slovak households about time allocation for paid and unpaid work and effect of household strategies on selected areas of the economy". The project is the most recent of three consecutive projects focused on systematic measuring of time use of Slovak households, as official statistics are missing in the region. In the presented analysis, we used data collected in 2017 using a questionnaire. Members of respondent household (older than 15) were supposed to fill in a time use diary, which captured their activities during one working and one free day. The diary records were recoded into following categories: sleep, personal care, travelling, paid work, study, housework, childcare, adult care, leisure and volunteering. The amount of unpaid work analysed in the paper includes sum of time devoted to housework (food preparation, washing up, cleaning, doing the laundry, ironing, house/garden/car repairs and maintenance, shopping, including online shopping, dealing with authorities), childcare, adult care and volunteering.

Within LIS database, we work with dataset collected in 2013 in Slovak households (we are aware of the time lag between time use data and income data, however, as it is reasonable to assume, that habits of the household are changing only slowly, we do not consider it to be significant). The dataset consists of 5490 households. For the purpose of our analysis we restrict the sample to couple-headed households living with or without children. The households which include another adult person except from couple are excluded as well. We also do not consider households in which at least one member is retired. It is due to comparability with other analysis of equalising effect of unpaid work (e.g. Frazis and Stewart, 2011; Frick et al., 2012; Folbre et al., 2013). The reason for the choice of the sample is the necessity to impute the value of unpaid work to dataset. The technique of imputation is based on assigning average value of unpaid work to the household according to certain typology. As to the fact that VEGA dataset consists of much smaller amount of observations (833 households), we need a typology of households which results in sufficient amount of observation for each type of household. Therefore, the 
reason for choosing couple headed household is firstly, the fact that they are most frequent among the households, and secondly, the individual types of households vary significantly considering amount of unpaid work. After these adjustments, we analyse 1884 observations form LIS dataset and 465 observations from the VEGA dataset.

To impute the value of unpaid work to LIS data, we use two different procedures. Firstly, we assume that amount of unpaid work is associated with life cycle of the household as well as with its income, as higher income allow household to substitute household production by products and services offered by market. Secondly, we assign the value of unpaid work according to employment status of the household, size of the city in which it lives and presence of a child below 5 .

As to the first approach to imputation of unpaid work, we start by defining life cycle typology. The typology we use (Table 1) is inspired by Anxo et al. (2011). We assume that the extent of unpaid work is implicitly given by the presence and age of the youngest child regardless of the size of the household. In addition, we distinguish between young childless couples and older empty-nest couples. We tackle the size of household by using equivalence scales. Using VEGA dataset, we calculate weighted average of unpaid work in the given types of the households (the dataset is weighted to ensure representativeness according to number of household members and region). To express the value of unpaid work, we use replacement cost approach and multiply the average time devoted to unpaid work by minimal hourly wage in 2013. Table 1 presents both average weekly time devoted to unpaid work by given type of the household as well as its yearly monetary value. The choice of income categories is substantially limited by the way how VEGA dataset measures the household income. It uses wide intervals to increase the probability of response. The middle category is centred around $1400 €$ which is roughly two times average net wage in 2017 (assuming both partners are participating in labour market).

Table 1: Average weekly time devoted to unpaid work and its yearly monetary value typology 1

\begin{tabular}{|c|c|c|c|}
\hline & \multicolumn{3}{|c|}{ Income category } \\
\hline & Below $1000 €$ & $1001-1900 €$ & Above $1901 €$ \\
\hline \multicolumn{4}{|l|}{ Average weekly time of unpaid work } \\
\hline young childless couples & $25.23 \mathrm{~h}$ & $27.10 \mathrm{~h}$ & $20.84 \mathrm{~h}$ \\
\hline couples with the youngest child $0-5$ years & $90.29 \mathrm{~h}$ & $74.47 \mathrm{~h}$ & $61.29 \mathrm{~h}$ \\
\hline couples with the youngest child $6-14$ years & $50.28 \mathrm{~h}$ & $47.78 \mathrm{~h}$ & $50.98 \mathrm{~h}$ \\
\hline couples with the youngest child $15-25$ years & $48.20 \mathrm{~h}$ & $38.53 \mathrm{~h}$ & $37.65 \mathrm{~h}$ \\
\hline middle-aged empty-nest couples & $46.64 \mathrm{~h}$ & $31.27 \mathrm{~h}$ & $30.30 \mathrm{~h}$ \\
\hline \multicolumn{4}{|l|}{ Yearly monetary value of unpaid work } \\
\hline young childless couples & $2553.43 €$ & $2742.51 €$ & $2109.25 €$ \\
\hline couples with the youngest child $0-5$ years & $9138.60 €$ & $7536.91 €$ & $6203.04 €$ \\
\hline couples with the youngest child $6-14$ years & $5088.30 €$ & $4835.73 €$ & $5159.83 €$ \\
\hline couples with the youngest child $15-25$ years & $4878.53 €$ & $3900.09 €$ & $3810.53 €$ \\
\hline middle-aged empty-nest couples & $4720.69 €$ & $3165.20 €$ & $3066.64 €$ \\
\hline
\end{tabular}

Source: the authors.

The second procedure of imputing the value of unpaid work is based on three features of households. Firstly, it is employment status - we distinguish between the households, in which both partners are employed and at least one is not employed. We consider also the size of the settlement, where households are living - we identify the household living in the seat of the regional municipality (in Slovak condition, it means that it have over 55000 inhabitants). Finally, we differentiate between households with small child below 5 and without small children. The average values of unpaid work for this typology both in weekly hours and in monetary terms (yearly value) are presented in Table 2 . 
Table 2: Average weekly time devoted to unpaid work and its yearly monetary value typology 2

\begin{tabular}{cccc}
\hline & & \multicolumn{2}{c}{ Employment status } \\
\cline { 3 - 3 } & & $\begin{array}{c}\text { At least one not } \\
\text { employed }\end{array}$ & $\begin{array}{c}\text { Both } \\
\text { employed }\end{array}$ \\
\hline Average weekly time of unpaid work & & \\
Seat of municipality & No child below 5 years & $48.60 \mathrm{~h}$ & $38.89 \mathrm{~h}$ \\
& Child below 5 years & $90.82 \mathrm{~h}$ & $61.21 \mathrm{~h}$ \\
Other settlement & No child below 5 years & $32.20 \mathrm{~h}$ & $34.46 \mathrm{~h}$ \\
Yearly monetary value of unpaid work & $84.53 \mathrm{~h}$ & $54.98 \mathrm{~h}$ \\
Seat of municipality & No child below 5 years & $4919.23 €$ & $3936.22 €$ \\
& Child below 5 years & $9191.49 €$ & $6194.95 €$ \\
Other settlement & No child below 5 years & $3259.18 €$ & $3487.28 €$ \\
\hline
\end{tabular}

Source: the authors.

Both procedures have theirs advantages and drawbacks. As to the first typology, we assume that with increasing income households tend to substitute their unpaid work by market services. It means we implicitly assume that market services are available in desired quality and households are willing to outsource it, what does not have to be true for certain regions and certain households. The second typology is based expectation, that a household member, who is currently not employed will intensify his/her household production. Empirical research however shows, that the determinants of unpaid work are more complex than simple time availability, including control over resources and gender display.

As a next step, we assign the value of unpaid work to households in LIS dataset according to given typology. We calculate the extended income by summing up household disposable income (total monetary and non-monetary current income net of income taxes and social security contributions) with the value of unpaid work. Table 3 summarises the distribution of disposable income, extended income using both procedures of imputation before and after applying equivalence scale (square root of number of household member).

Table 3: Distribution of household disposable and extended income (yearly)

\begin{tabular}{lccccc}
\hline & Min & 1st quartile & Mean & 3rd quartile & Max \\
\hline Disposable income (in $€$ ) & 200 & 11833 & 17264 & 20167 & 339810 \\
Equalised disposable income (in $€$ ) & 141 & 6059 & 8871 & 10443 & 169905 \\
Extended income - typology 1 (in $€$ ) & 4117 & 17303 & 22613 & 25487 & 343620 \\
Equalised ex income - typology 1(in $€$ ) & 2821 & 8932 & 11598 & 13189 & 171810 \\
Extended income - typology 2 (in $€$ ) & 3536 & 16832 & 22254 & 25144 & 343746 \\
Equalised ex income - typology 2 (in $€$ ) & 1907 & 8545 & 11431 & 13082 & 171873 \\
\hline
\end{tabular}

Source: the authors.

\section{Results}

To describe differences in regional disparities concerning disposable income and extended income, table 4 presents their weighted average in regions of Slovakia - both in absolute terms as well as a portion of income in Bratislava region. 
Table 4: Average equalised disposable and extended income of households in regions of Slovakia (yearly)

\begin{tabular}{|c|c|c|c|c|c|c|c|c|}
\hline Type of income / Region & BA & TT & TN & NR & $\mathrm{BB}$ & $\mathrm{ZA}$ & PO & $\mathrm{KE}$ \\
\hline Disposable income (absolute, in $€$ ) & 11581 & 9500 & 9164 & 8425 & 8582 & 8028 & 8084 & 8225 \\
\hline Disposable income (\% of BA region) & $100 \%$ & $82 \%$ & $79 \%$ & $73 \%$ & $74 \%$ & $69 \%$ & $70 \%$ & $71 \%$ \\
\hline Extended income - typology 1 (absolute, in $€)$ & 14367 & 12089 & 11844 & 11104 & 11350 & 10845 & 10831 & 10958 \\
\hline Extended income - typology 1 (\% of BA region) & $100 \%$ & $84 \%$ & $82 \%$ & $77 \%$ & $79 \%$ & $75 \%$ & $75 \%$ & $76 \%$ \\
\hline Extended income - typology 2 (absolute, in $€)$ & 14136 & 11944 & 11740 & 10901 & 11223 & 10728 & 10683 & 10707 \\
\hline Extended income - typology 2 (\% of BA region) & $100 \%$ & $84 \%$ & $83 \%$ & $77 \%$ & $79 \%$ & $76 \%$ & $76 \%$ & $76 \%$ \\
\hline
\end{tabular}

Using our results, income inequality within Slovakia is calculated by applying selected inequality indicators (Table 5).

Table 5: Inequality indicators for equalised disposable and extended income

\begin{tabular}{cccc}
\hline Inequality indicator & Disposable income & $\begin{array}{c}\text { Extended income - } \\
\text { typology 1 }\end{array}$ & $\begin{array}{c}\text { Extended income - } \\
\text { typology 2 }\end{array}$ \\
\hline Gini & 0.278 & 0.202 & 0.211 \\
Atkinson $(\varepsilon=0.5)$ & 0.070 & 0.037 & 0.039 \\
Atkinson $(\varepsilon=1.0)$ & 0.139 & 0.070 & 0.075 \\
Percentile ratio $(90 / 10)$ & 3.420 & 2.282 & 2.426 \\
Percentile ratio $(90 / 50)$ & 1.759 & 1.545 & 1.563 \\
Percentile ratio $(80 / 20)$ & 2.038 & 1.634 & 1.695 \\
\hline
\end{tabular}

Source: the authors.

Both tables show that after incorporating value of unpaid work, the distribution of the income moves to higher equality, so positively. The result is robust to the different types of inequality indicators. Considering significant change in Atkinson index $(\varepsilon=1.00)$ and 90th/10th percentile ratio, we can conclude, that the change in inequality was mainly driven by higher increase in income in the bottom of distribution than in other groups. Our results can be partially useful to answer the current challenge of international comparison in household economy issues (Badarinza et al., 2016). In comparison to research done in the other countries, the difference reaches the lower border. Folbre et al. (2013) compare the distribution of market and extended income for representatives of European countries and find out that as to the Gini coefficient the difference for market and extended income ranges from 0.19 for Poland to 0.06 for United states. The difference for Slovakia equal to 0.076 and 0.067 respectively for imputation using typology 1 and 2 mean values. Frazis and Stewart (2011) identified decrease in Gini coefficient by 0.091 for US data analysing both couple-headed as well as single-member household. Frick et al. (2012) evaluated change in inequality for even wider sample of German households using a more exact regression method of imputing value of unpaid work. They observed change in Gini coefficient from 0.298 for market income to 0.257 for extended income.

\section{Conclusion}

The main aim of our analysis was to offer an alternative perspective to the issue of income inequality measurement. The fulfilment of this aim is based on comparing indicators of inequality and regional disparities for market disposable household income and extended income which includes also the value of unpaid work. Based on the Luxembourg income study data of disposable market income and imputation of value of unpaid work based on time use diaries, we found out that the extended income has more equal distribution than disposable market income. However, in comparison to similar researches in other countries, the equalising effect is moderate. The reason could be seen in the following circumstances. 
Firstly, the logic behind of equalising effect is the assumption that households with higher income substitute their unpaid work for market services so that they can enjoy more leisure. And vice versa, the household with lower income should have tendency to carry out more unpaid work, in order to get necessary consumption goods with lower costs. The time use data, however, do not show any clear tendency between income and extent of unpaid work in Slovakia. This can be partially caused by the fact that we focus our analysis on the coupleheaded households. The households with children below 5 differ significantly in the extent of unpaid work for each income level. From the regional point of view, the areas with highest income levels tend to attract young families. It is also the case of Slovakia, in the region of Bratislava, characterised by the highest incomes and higher proportion of young families than in the other regions.

Secondly, lower equalising effect in comparison to other European countries could be caused by the value of unpaid work itself. The methodology of evaluation of unpaid work was based on replacement cost i.e. the value of unpaid work is equal to wage of a worker who performs similar services on the market (approximated by minimum wage). In Slovakia, there is significantly lower minimal wage than in western European countries. Therefore, the differences in the extent of unpaid work expressed in hours is less notable in the countries with lower minimal wage.

Nevertheless, the analysis points out the significant contribution of unpaid work to welfare level of the household. The highest "time investment" of households are connected to rearing children. As the production capacity of the "future workforce" will determine the income level of future retired people (assuming existing welfare system), children should be seen as important contribution to welfare of the whole society and therefore incentivised. Having children, however decrease market income of households, especially income of mothers.

Limitations of these analysis results from both methodology as well as the available data. Firstly, to evaluate the value of unpaid work, we used simple method of replacement cost using generalist approach to calculation of its value. It means that all the time spend by performing unpaid work in households were multiplied by the same sum of money representing a wage of a "general" household worker. Use of the specialist approach, i.e. by evaluating various activities of unpaid work by hourly wage of corresponding specialist, would allow us to differentiate between varieties of structure of unpaid work in Slovak households. Secondly, we use mean substitution method of imputing value of unpaid work to LIS disposable income dataset. As it was pointed out by Frazis and Stewart (2011), adding large constants to distribution itself decreases the inequality of such a distribution. Thirdly, using of equivalence scale could be improved. As to the character of unpaid work, it is reasonable to think about higher extent of economies of scale in connection to household unpaid work. Therefore, to get more exact picture of household welfare, different equivalence scales should be used equalizing market income and equalizing value of unpaid work. Finally, both time use researches as well as income surveys are limited in capturing both very poor as well as very rich households.

However, our results are promising and motivate to identification of economic policy implications. We see them firstly at the methodological level - including the value of unpaid work to national accounting system in order to get better picture about income inequality and regional disparities in Slovakia. Secondly, we identify the possibilities for improvement at the level of economic policy actions. Both paid and unpaid work have a potential to increase a society welfare, so they should be recognising by economic policy subjects at an equal level and should be supported by state institutions to the same extent. 


\section{Acknowledgements}

The paper was supported by the grant scheme VEGA No. 1/0621/17 "Decision-making of Slovak households about time allocation for paid and unpaid work and effect of household strategies on selected areas of the economy".

\section{References}

[1] Anxo, D. et al., 2011. Gender differences in time use over the life course in France, Italy, Sweden, and the US. In Feminist Economics, 2011, vol. 17, iss. 3, pp. 159-195.

[2] Badarinza, C., Campbell, J. Y., Ramadorayi, T. 2016. International comparative household finance. In Annual Review of Economics, 2016, vol. 8, pp. 111-144.

[3] Brouen, D., Koedijk, K. G., Pownall, R. A. J. 2016. Household financial planning and savings behavior. In Journal of International Money and Finance, 2016, vol. 69, pp. 95-107.

[4] Folbre, N. et al. 2013. Women's employment, unpaid work, and economic inequality. In Gornick, J. C. and Jantti, M. (eds.). Income inequality: Economic disparities and the middle class in affluent countries. Redwood : Stanford University Press, 2013. ISBN 978-0-80477824-4.

[5] Folbre, N., Murray Close, M. 2014. Unpaid work, unpriced services, and equivalence scales. Paper presented at the IARIW 33rd General Conference. [cit. 2019-03-31] http://www.iariw.org/papers/2014/FolbrePaper.pdf.

[6] Frazis, H., Stewart, J., 2011. How does household production affect measured income inequality? In Journal of Population Economics, 2011, vol. 24, iss. 1, pp. 3-22.

[7] Frick, J. R., Grabka, M. M., Groh-Samberg, O. 2012. The impact of home production on economic inequality in Germany. In Empirical Economics, 2012, vol. 43, iss. 3, pp. 1143-1169.

[8] Kaščáková, A. 2016. Metodológia skúmania neplatenej práce. In Uramová, M., Orviská, M. (eds.), Neplatená práca na Slovensku. Banská Bystrica : Belianum, 2016. ISBN 978-80-557-1158-4.

[9] Molina, J. A. 2011. Households economic behaviors. New York : Springer, 2011. ISBN 978-1-4419-9431-8.

[10] Monfort, P. 2008. Convergence of EU regions - measures and evolution. Regional Policy Working Paper No. 1/2008. Brussels : European Commission, 2008. [cit. 2019-04-21] https://ec.europa.eu/regional_policy/sources/docgener/work/200801_convergence.pdf.

[11]Procházka, D. 2009. The Hicks' concept of income and its relevancy for accounting purposes. In European Financial and Accounting Journal, 2009, vol. 4, iss. 1, pp. 37-60.

[12] United Nations Economic Commission for Europe 2011. Canberra Group handbook on household income dtatistics. 2nd ed. [cit. 2019-03-03] http://www.unece.org/fileadmin/ DAM/stats/publications/Canberra_Group_Handbook_2nd_edition.pdf. 